\title{
ANALISIS KESULITAN BELAJAR SISWA PADA PEMBELAJARAN MATEMATIKA MATERI PECAHAN DILIHAT DARI KEMAMPUAN MENYELESAIKAN PEMECAHAN MASALAH MATEMATIKA KELAS IV SD NEGERI 2 TLOGOTUNGGAL KABUPATEN REMBANG
}

\author{
Ripit Apriliana ${ }^{1)}$ Ervina Eka Subektii ${ }^{2)}$,M. Yusuf Setia Wardana ${ }^{3)}$ \\ Universitas PGRI Semarang \\ E-mail: ripit20april@gmail.com
}

\begin{abstract}
Abstrak
Kata Kunci:

Kesulitan belajar, Pemecahan masalah matematika, Pecahan.

Tujuan penelitian ini untuk mengetahui kesulitan belajar siswa dan mendeskripsikan faktor-faktor yang mempengaruhi kesulitan belajar siswa kelas IV SD Negeri 2 Tlogotunggal Kabupaten Rembang dilihat dari kemampuan menyelesaikan pemecahan masalah matematika materi pecahan. Metode penelitian yang digunakan dalam penelitian ini adalah kualitatif dengan pendekatan deskriptif. Subjek penelitian ini adalah siswa kelas IV SD Negeri 2 Tlogotunggal Kabupaten Rembang yang berjumlah 25 siswa. Teknik pengumpulan data dalam penelitian ini menggunakan observasi, soal, angket, wawancara dan dokumentasi. Hasil penelitian ini menunjukan bahwa siswa mengalami kesulitan belajar dalam pemecahan masalah matematika materi pecahan (a) Memahami masalah sebanyak 30\%, merencanakan pemecahan masalah sebanyak $55,2 \%$, melaksanakan rencana pemecahan masalah sebanyak $58 \%$, dan memeriksa kembali sebanyak $83,6 \%$. (b) Faktor yang mempengaruhi kesulitan belajar dalam kemampuan pemecahan masalaha matematika yaitu pada aspek lingkungan keluarga dan aspek lingkungan sekolah.
\end{abstract}

\section{Abstract:}

Keyword: Learning difficulties, Mathematical problem solving, Fractional.
The purpose of this study was to determine the learning difficulties of students and to describe the factors that affect the learning difficulties of grade IV students of SD Negeri 2 Tlogotunggal Regency of Rembang as seen from their ability to solve mathematical problem solving in fraction material. The research method used in this research is qualitative with a descriptive approach. The subjects of this study were the fourth grade students of SD Negeri 2 Tlogotunggal, Rembang, totaling 25 students. Data collection techniques in this study used observation, questions, questionnaires, interviews and documentation. The results of this study indicate that students have learning difficulties in solving math problems with fractions (a) Understanding the problem by $30 \%$, planning problem solving as much as $55.2 \%$, implementing problem solving plans as much as 58\%, and checking back as much as $83.6 \%$. (b) Factors that affect learning difficulties in math problem solving abilities are the aspects of the family environment and aspects of the school environment. 


\section{Pendahuluan}

Pendidikan memiliki peranan yang sangat penting dalam pembentukan sumber daya manusia yang berkualitas, terutama dalam mengembangkan potensi manusia untuk mewujudkan cita-cita atau tujuan yang ingin dicapai. Pendidikan merupakan suatu aspek yang terpenting dalam hidup setiap manusia sejak dulu hingga sekarang karena pendidikan sebagai penentu dalam membangun bangsa agar lebih baik kedepannya ( Fauziah, Reffiane, \& Sukamto, 2019).

Matematika merupakan mata pelajaran yang memiliki peranan yang penting dalam pendidikan, serta mendukung perkembangan ilmu pengetahuan dan teknologi (Muslimah, Subekti dan Soegeng, 2019). Namun, matematika menjadi salah satu mata pelajaran dengan tingkat kesulitan belajar paling banyak yang dialami oleh siswa. Hal tersebut dikarenakan masih banyak siswa yang kemampuan berhitungnya masih rendah, sulit memahami soal matematika terutama dalam memecahkan soal. Sejalan dengan pendapat menurut Fitriyani dan Wardana (2019: 70) bahwa matematika merupakan momok yang sangat manakutkan bagi sebagian siswa dan langsung maupun tidak langsung mematikan minat belajar siswa dalam belajar matematika.
Menurut Djamaris, (2015: 3) bahwa Kesulitan belajar learning disability adalah suatu kelainan yang membuat individu yang bersangkutan sulit untuk melakukan kegiatan belajar secara efektif. Faktor yang menjadi penyebab kesulitan belajar tidaklah mudah untuk ditetapkan karena faktor tersebut bersifat kompleks. Siswa yang mengalami kesulitan belajar matematika mempunyai beberapa karakteristik. Siswa berkesulitan belajar sering melakukan kekeliruan dalam belajar berhitung, kekeliruan dalam belajar geometri dan kekeliruan dalam menyelesaikan soal cerita (Runtukahu dan Kandou, 2014: 252).

Pemecahan masalah merupakan bagian dari kurikulum matematika yang sangat penting karena dalam proses pembelajaran siswa dimungkinkan memperoleh pengalaman menggunakan pengetahuan serta keterampilan yang sudah dimilikinya untuk diterapkan pada pemecahan masalah yang bersifat tidak rutin. Menurut Mulyadi dalam Widyasari dkk (2015: tidak ada nomor halaman )rendahnya hasil belajar peserta didik merupakan salah satu patokan adanya gejala kesulitan belajar.

\section{Metode}

Peneliti menggunakan pendekatan kualitatif deskriptif yang bertujuan untuk mengetahui jenis kesulitan belajar pada 
siswa dan faktor-faktor penyebab kesulitan belajar dilihat pada kemampuan pemecahan masalah matematika materi pecahan di kelas IV SD Negeri 2 Tlogotunggal Kabupaten Rembang. Menurut Moleong (2013: 6) mengemukakan bahwa penelitian kualitatif adalah penelitian yang bertujuan untuk memahami keadaan yang dialami oleh subjek penelitian, secara holistik dan diskriptif dalam bentuk kata-kata dan bahasa, pada suatu konteks khusus yang alamiah dan dengan memanfaatkan berbagai metode alamiah. Pendekatan kualitatif yang dilakukan dalam penelitian ini bertujuan untuk mengumpulkan fakta dan data yang akurat untuk mengetahui jenis kesulitan belajar pada siswa dan faktor-faktor yang mempengaruhi kesulitan belajar pada kemampuan pemecahan masalah matematika materi pecahan pada siswa kelas IV SD Negeri 2 Tlogotunggal Kabupaten Rembang. Data-data tersebut selanjutnya akan dianalisis dengan tujuan untuk mengetahui kesulitan matematika dan faktor-faktor yang mempengaruhi kesulitan belajar dalam pemecahan masalah matematika pada siswa kelas IV SD Negeri 2 Tlogotunggal Kabupaten Rembang.

Subjek penelitian dipilih berdasarkan teknik pengambilan sampling purposive. Sampling purposive adalah teknik pengambilan sumber data dengan pertimbangan tertentu (Sugiyono, 2015: $85)$.

\section{Hasil dan Pembahasan}

Berdasarkan hasil analisis data hasil penelitian yang telah dilakukan pada siswa kelas IV SD Negeri 2 Tlogotunggal Kabupaten Rembang dapat diketahui bahwa terdapat kesulitan belajar pemecahan masalah matematika materi pecahan. Berdasarkan dari hasil data soal, wawancara guru, siswa dan angket diperoleh bahwa siswa masih kesulitan belajar dalam pemecahan masalah matematika materi pecahan. Siswa masih belum menguasai konsep dasar perkalian dan pembagian, mengakibatkan ketika siswa mencari kelipatan atau KPK mengalami kesalahan dalam berhitung. Sebagian dari siswa juga belum bisa menyamakan penyebut dalam penyebut yang berbeda. Dalam memecahkan masalah matematika, pada tahap memahami masalah sebagian siswa sudah mampu memahami masalah soal rutin dan non rutin.

Dari hasil data siswa dapat diketahui bahwa siswa mengalami kesulitan mulai dari merencanakan masalah matematika, melaksanakan rencana pemecahan masalah. Hal ini dikarenakan siswa belum menguasai konsep dasar perkalian dan pembagian, mencari kelipatan dan 
menyamakan penyebut. Sehingga siswa kesulitan dalam merencanakan pemecahan masalah matematika dan melaksankan rencana. Untuk tahap memeriksa kembali atau memberikan kesimpulan sebagian kecil siswa sudah mampu memeriksa kembali atau memberikan kesimpulan. sebagian kecil lainnya masih belum mampu memeriksa kembali atau memberikan kesimpulan. Karena kebanyakan dari siswa ketika susdah selesai mengerjakan, siswa malah untuk meneliti soal lagi sepeti membaca soal, mengerjakan, dan menghitung lagi soal, serta memberikan kesimpulan pada soal.

Faktor-faktor yang mempengaruhi kesulitan belajar pemecahan masalah matematika materi pecahan pada siswa kelas IV SD Negeri 2 Tlogotunggal Kabupaten Rembang yaitu faktor internal merupakan faktor yang ada di dalam diri sendiri seseorang. Faktor internal terdiri dari 3 aspek yaitu aspek kognitif, aspek afektif dan psikomotorik. Adapun faktor internal yang mempengaruhi kesulitan belajar dalam pemecahan masalah matematika selain aspek kognitif adalah Aspek afektif atau sikap siswa didasarkan pada kestabilan emosi siswa yang mengalami kesulitan belajar. Dari hasil wawancara, observasi dan angket, siswa megalami kesulitan belajar dalam pemecahan masalah matematika disebabkan oleh aspek afektif, hal ini dikarena karena sebagian dari siswa sering marah-marah tanpa alasan, mengganggu teman-temannya, sering bertengkar dan siswa yang mengalami kesulitan belajar seringkali dijauhi oleh teman-temanya. Hal ini juga dibuktikan dari angket, wawancara siswa dan wawancara guru. Sikap siswa ketika dalam pembelajaran, siswa sering kurang memperhatikan ketika guru menjelaskan atau dalam pembelajaran. Siswa sering kurang semangat dalam mengikuti pembelajaran matematika karena menganggap bahwa matematika adalah mata pelajaran yang paling sulit.

$$
\text { Selanjutnya faktor eksternal }
$$

merupakan faktor yang ada di luar diri seseorang. Faktor eksternal terdiri dari aspek lingkungan keluarga, aspek lingkunga sekolah dan aspek lingkungan masyarakat. Adapun faktor eksternal yang mempengaruhi kesulitan belajar dalam pemecahan masalah matematika adalah aspek lingkungan keluarga yang mempengaruhi kesulitan belajar didasarkan pada perhatian orangtua kepada anak. Dari hasil analisis data bahwa kebanyakan dari orangtua siswa kurang memperdulikan kesulitan belajar anak ketika di sekolah. Semuanya diserahkan kepada guru, sehingga siswa mengalami kesulitan dalam belajar. Karena banyak orangtua tidak memperdulikan ketika anak dirumah. 
Sebagian besar orangtua bekerja sebagai buruh.

Aspek lingkungan sekolah yang mempengaruhi kesulitan belajar berdasarkan dari analisis data wawancara siswa, wawancara guru, observasi dan angket bahwa penggunaan media pembelajaran media pembelajaran yang mempengaruhi kesulitan belajar pemecahan masalah matematika. ketika pembelajaran matematika materi mengurutkan pecahan guru tidak menggunakan media pembelajaran, yang mengakibatkan siswa merasa kurang semangat dan kurang tertarik untuk belajar didalam kelas ketika materi yang disampaikan guru tidak tersampaikan dengan baik. Berdasarkan dari hasil analisis data diperoleh bahwa ketika pembelajaran guru hanya menggunakan metode ceramah, diskusi, tanya jawab dan tugas. Metode yang digunakan kurang maksimal, sehingga dalam pembelajaran siswa merasa bosan. Selain itu, guru juga kurang memberikan latihan soal pemecahan masalah matematika non rutin, sehingga siswa belum faham tentang soal non rutin.

\section{Kesimpulan}

Berdasarkan hasil penelitian dan pembahasan analisis kesulitan belajar pemecahan masalah matematika kelas IV SD Negeri 02 Tlogotunggal Kabupaten
Rembang diperoleh simpulan sebagai berikut: Kesulitan belajar siswa dalam memecahkan masalah matematika materi pecahan yang terjadi di kelas IV SD Negeri 2 Tlogotunggal Kabupaten Rembang meliputi: (a) Kesulitan siswa dalam memahami masalah sebanyak 30\%, (b) Kesulitan dalam merencanakan pemecahan masalah sebanyak 55,2\%, (c) Kesulitan dalam melaksanakan rencana sebanyak 58\%dan d) Kesulitan dalam memeriksa kembali atau memberikan kesimpulan sebanyak 83,6\%. Kesulitan belajar pemecahan masalah matematika materi pecahan ini, didasari dengan adanya bukti penelitian berupa jawaban lembar wawancara dari narasumber, lembar hasil pekerjaan siswa, angket dan dokumentasi.

Faktor yang mempengaruhi kesulitan belajar pemecahan masalah matematika materi pecahan di SD Negeri 2 Tlogotunggal Kabupaten Rembang terdiri dari dua faktor diantaranya yaitu faktor internal dan faktor eksternal. Faktor internal yang mempengaruhi kesulitan belajar dari dalam diri siswa adalah aspek afektif. Aspek afektif ini berupa ketidakstabilan emosi siswa ditandai dengan siswa yang sering merah-marah tanpa alasan yang jelas. Sedangkan faktor eksternal yang berasal dari luar diri siswa meliputi aspek lingkungan keluarga dan lingkungan sekolah. Lingkungan keluarga 
yang mempengaruhi kesulitan belajar karena faktor kurangnya perhatiannya orangtua kepada anak ketika dirumah. Lingkungan sekolah yang mempengaruhi kesulitan belajar dikarenakan faktor kurangnya penggunaan media pembelajaran dan kurangnya variasi guru dalam mengajar.

Simpulan dapat bersifat generalisasi temuan sesuai permasalahan penelitian, dan berupa rekomendatif untuk langkah selanjutnya. Di dalam simpulan dapat menjelaskan saran-saran berupa masukan bagi peneliti berikutnya, dan rekomendasi implikatif dari temuan penelitian.

\section{Daftar Pustaka}

Dewi, N. W. (2019). Analisis Kesulitan Belajar Matematika Pada Siswa Kelas III SD Negeri Semampir 01 Kabupaten Batang. Skripsi : Universitas PGRI Semarang.

Fauziah, R., Reffiane, F., \& Sukamto. (2019). Analisis Kesulitan Belajar Materi Operasi Hitung Pembagian Pada Siswa Kelas 3 SDN Gebangsari o2. Jurnal Basicedu, 3(2), 838- 843.

Jamaris, M. (2014). Kesulitan Belajar. Dalam Perspektif, Asesemen, dan Penanggulangannya Bagi Anak Usia Dini dan Usia Sekolah. Bogor.

Kompri. (2017). Belajar Faktor-faktor yang Mempengaruhi. Yogyakarta: Media Akademik.
Muslimah, Siti. Subekti, Ervina. Eka dan Soegeng Ysh, A.Y. Keefektifan Pendekatan Pendidikan Matematika Realistik Indonesia Berbantu Media Dhakon Terhadap Kemampuan Pemecahan Masalah Matematika Siwa Kelas IV sd Khusuma Bhakti Semarang. Artikel.

Volume 1, Nomor 1 Tahun 2019. http://conference.upgris.ac.id/ind ex.php/sendika/article/view/361/ $\underline{206}$

Runtukahu, T., \& Kandou, S. (2016). Pembelajaran Matematika Dasar Bagi Anak Berkesulitan Belajar. Yogyakarta: Ar-Ruzz Media.

Sugiyono. (2016). Metode Penelitian Pendidikan. Dalam Pendekatan Kuantitatif, Kualitatif, dan R\&D. Bandung: Alfabeta.

Fitriyani, A.Z. dan Wardana, M.Y.S 2019. Implementasi Model RME Dengan Media Pizza Pecahan Terhadap Hasil Belajar Kognitif Matematika Siswa. Jurnal Malih Pedas, P-ISSN: 2088-5792; EISSN: 2580-6513 Volume 9, Nomor 1 Juli 2019 http://journal.upgris.ac.id/index.p $\underline{\mathrm{hp} / \text { malihpeddas }}$

Widyasari, N. M., Meter, I. G., \& Negara, I. A. (2015). Analisis Kesulitan-Kesulitan Belajar Matematika Siswa Kelas IV dalam Implementasi Kurikulum 2013 Di SD Piloting SeKabupaten Gianyar. e-Journal PGSD Universitas Pendidikan Ganesha, 3(1). 